\begin{tabular}{|c|c|c|}
\hline Fallupr $\mathrm{Dh}$ & Cell Physiol Biochem 2012;30:359-371 & \\
\hline n & $\begin{array}{l}\text { DOI: } 10.1159 / 000339070 \\
\text { Published online June } 29.2012\end{array}$ & $\begin{array}{l}\text { o } 2012 \text { S. Karger AG, Basel } \\
\text { www.karger.com/cpb }\end{array}$ \\
\hline & Accepted: May 21, 2012 & $1015-8987 / 12 / 0302-0359 \$$ \\
\hline
\end{tabular}

\title{
Pharmacological Differences of Endothelin Receptors-mediated Modulation in Cultured Interstitial Cells of Cajal from the Murine Small and Large Intestine
}

\author{
Byung Joo Kim ${ }^{1}$ In Youb Chang ${ }^{2}$ Insuk So ${ }^{3}$ \\ ${ }^{1}$ Division of Longevity and Biofunctional Medicine, Pusan National University School of Korean \\ Medicine, Yangsan, 'Department of Anatomy, Chosun University College of Medicine, Gwangju, \\ ${ }^{3}$ Department of Physiology, Seoul National University College of Medicine, Seoul
}

\section{Key Words}

Interstitial Cells of Cajal $\cdot$ Pacemaker potentials $\cdot$ Endothelin $\cdot \mathrm{ET}_{\mathrm{A}}$ receptor $\cdot \mathrm{ET}_{\mathrm{B}}$ receptor • Intestinal motility

\begin{abstract}
Interstitial cells of Cajal (ICCs) are pacemaker cells that activate the periodic spontaneous depolarization (pacemaker potentials) responsible for the production of slow waves in gastrointestinal smooth muscle. Under current clamping, ICCs had a mean resting membrane potential of $-58 \pm 3 \mathrm{mV}$ and externally applied ET produced membrane depolarization in a dosedependent manner. These effects were reduced by intracellular GDP beta S. A comparison of the concentration-dependent membrane depolarizations on pacemaker potentials to ET-1, ET-2 and ET-3 showed a rank order of potency ET-1 $\geq E T-2 \geq E T-3$ in cultured murine small intestinal ICCs. The pretreatment with $\mathrm{Ca}^{2+}$-free solution and thapsigargin, a $\mathrm{Ca}^{2+}$-ATPase inhibitor in endoplasmic reticulum, abolished the generation of pacemaker potentials and suppressed the ET-1 induced membrane depolarizations. Chelerythrine and calphostin C, protein kinase $C$ inhibitors or naproxen, an inhibitor of cyclooxygenase, did not block the ET-1 induced effects on pacemaker potentials. Pretreatment with BQ-123 (ET receptor antagonist) or BQ-788 (ET receptor antagonist) blocked the ET-1 induced effects on pacemaker potentials in cultured murine small intestinal ICCs. However, pretreatment with BQ-788 selectively did not block the ET-1 induced effects on pacemaker potentials in cultured murine large intestinal ICCs. Also, only externally applied selective $\mathrm{ET}_{\mathrm{B}}$ receptor agonist, IRL 1620 did not show any influence on pacemaker potentials in cultured murine large intestine ICCs. RT-PCR results indicated the presence of the $\mathrm{ET}_{\mathrm{A}}$ and $\mathrm{ET}_{\mathrm{B}}$ receptor in ICCs. These results suggested that ET-1 modulates pacemaker potentials through $\mathrm{ET}_{\mathrm{A}}$ and $\mathrm{ET}_{\mathrm{B}}$ receptor activation in murine small intestinal ICCS and $\mathrm{ET}_{A}$ receptor activation in murine large intestinal ICCs by external $\mathrm{Ca}^{2+}$ influx and internal $\mathrm{Ca}^{2+}$ release via protein kinase $\mathrm{C}$ or cyclooxygenase-independent mechanism. Therefore, the ICCs are targets for ET and their interaction can affect intestinal motility.
\end{abstract}




\begin{tabular}{|c|c|c|}
\hline \multirow{3}{*}{$\begin{array}{l}\text { Cellular Physiolosy } \\
\text { and Biochemistry }\end{array}$} & \\
\hline & $\begin{array}{l}\text { DOI: } 10.1159 / 000339070 \\
\text { Published online: June 29, } 2012\end{array}$ & $\begin{array}{l}\text { (c) } 2012 \text { S. Karger AG, Basel } \\
\text { www.karger.com/cpb }\end{array}$ \\
\hline & Kim/Chang/So: Role of ET on ICCs & \\
\hline
\end{tabular}

\section{Introduction}

The gastrointestinal (GI) tract shows spontaneous mechanical contractions, mediated by the periodic generation of electrical pacemaker potentials, which are basic determinant of GI smooth muscle activity [1]. Recent studies have shown that the interstitial cells of Cajal (ICCs) act as the pacemakers and conductors of the electrical slow waves in GI smooth muscles [2-6]. Moreover there is evidence that endogenous agents such as neurotransmitters, hormones and paracrine substances modulate GI tract motility by influencing the ICCs [711].

Endothelins (ETs) are a family of peptides with 21 amino acid residues. ET-1 was originally identified in 1988 as a potent vasoconstrictor produced by vascular endothelial cells $[12,13]$. The ET system comprises three potent, vasoactive autacoids named ET-1, ET-2 and ET-3, several isoforms of ET converting peptidases, and two G-protein coupled transmembrane receptors: $\mathrm{ET}_{\mathrm{A}}$ and $\mathrm{ET}_{\mathrm{B}}$ [14-16]. Of the three ET isoforms $(1,2$, and 3), ET-1 has been studied most extensively. ET-1 is expressed in endothelial cells, cardiomyocytes, smooth muscle cells, epithelial cells of lung, renal tubules, intestine, urinary tract, uterus, and in neutrophiles, monocytes, mast and Sertoli cells [17]. ET-1 regulates function of the blood vessels and heart whereas in the kidney it modulates vascular and mesangial tone, water and sodium turnover and cell proliferation [18-20]. In the literature there are strong data indicating on the involvement of ETs in physiology and pathophysiology of GI tract. ET-1 is expressed in GI tissues including vascular endothelium, submucosa stroma and circularis muscularis layers of the gut [21]. The effects of ET-1 on smooth muscle are mediated through at least two distinct subtypes of receptors, namely the endothelin type $\mathrm{A}\left(\mathrm{ET}_{\mathrm{A}}\right)$ receptors and the endothelin type $\mathrm{B}\left(\mathrm{ET}_{\mathrm{B}}\right)$ receptors [22]. ET-1 acts through the Gprotein-IP ${ }_{3}$ pathway, which increases intracellular free $\mathrm{Ca}^{2+}$ by triggering influx from outside of the cells and the release of $\mathrm{Ca}^{2+}$ from intracellular stores [17]. The mounting interest in ET research, coupled with the discovery of potent agonists and antagonists, may lead to a better understanding of the pathogenic mechanisms in the GI tract and the development of novel therapies for GI disorders. Moreover, the discovery of potent ET antagonists and the recent demonstration of their effectiveness in animal models of pathology such as Hirschsprung's disease [23], has provided preliminary evidence that endogenous ETs may be of importance in the pathogenesis of human diseases $[17,24,25]$. The following studies have reported the diverse effects of ET-1 on vascular and non-vascular smooth muscle. In several regions of the GI tract, ET-1 elicits biphasic effects on smooth muscle, with an initial relaxation followed by a sustained contraction [26-29]. ET-1 also has dual effects on slow waves in the rat gastric antrum, through different types of receptors. ET- 1 hyperpolarizes the membrane via $\mathrm{ET}_{\mathrm{A}}$ receptors, and depolarizes the membrane and increases the frequency of slow waves via $\mathrm{ET}_{\mathrm{B}}$ receptors [30]. As these experiments were performed in intact tissues, it was difficult to differentiate between the effects on ICCs and those on smooth muscle. Therefore, in this study, we investigated the effects of ET on the electrical properties of cultured ICCs, in order to elucidate the mechanisms of the effects of ET on intestinal motility.

\section{Materials and Methods}

\section{Materials}

ET-1, ET-2, ET-3, BQ-123, BQ-788, and IRL 1620 were purchased from TOCRIS (Bristol, UK). Chelerythrine, calphostin C and naproxen were purchased from Sigma (St. Louis, MO, USA). For stock solutions, all drugs were dissolved in distilled water or dimethylsulfoxide and stored at $-20^{\circ} \mathrm{C}$.

\section{Preparation of cells and cell cultures}

All experiments were carried out according to the guiding principles for the care and use of animals approved by the ethics committee in Pusan National University and the National Institutes of Health Guide for the care and Use of Laboratory Animals, and every effort was made to minimize both the number of animals used and their suffering. Balb/c mice (7-12 days old) of either sex were anaesthetized with ether 


\begin{tabular}{rl|l} 
Cellular Physiology & \multicolumn{1}{l}{ Cell Physiol Biochem 2012;30:359-371 } \\
\cline { 2 - 3 } DOI: 10.1159/000339070 & \multicolumn{2}{l}{$\begin{array}{l}\text { O 2012 S. Karger AG, Basel } \\
\text { www.karger.com/cpb }\end{array}$} \\
and Biochemistry & $\begin{array}{l}\text { Published online: June 29, 2012 } \\
\text { Kim/Chang/So: Role of ET on ICCs }\end{array}$
\end{tabular}

and sacrificed by cervical dislocation. The small intestines from $1 \mathrm{~cm}$ below the pyloric ring to the caecum were removed and opened along the mesenteric border. Luminal contents were washed away with KrebsRinger bicarbonate solution. The tissues were pinned to the base of a Sylgard dish and the mucosa was removed by sharp dissection. Small tissue stripes of intestine muscle (consisting of both circular and longitudinal muscles) were equilibrated in $\mathrm{Ca}^{2+}$-free Hank's solution (containing in $\mathrm{mM}$ : $\mathrm{KCl} 5.36, \mathrm{NaCl} 125$, $\mathrm{NaOH} 0.34, \mathrm{Na}_{2} \mathrm{HCO}_{3} 0.44$, glucose 10, sucrose 2.9 and HEPES 11) for $25 \mathrm{~min}$. Then, the cells were dispersed with an enzyme solution containing collagenase (Worthington Biochemical Co, Lakewood, NJ, U.S.A.) 1.5 $\mathrm{mg} / \mathrm{ml}$, bovine serum albumin (Sigma Chemical Co., St Louis, MO, U.S.A.) $3 \mathrm{mg} / \mathrm{ml}$, trypsin inhibitor (Sigma) $1.5 \mathrm{mg} / \mathrm{ml}$ and ATP $0.3 \mathrm{mg} / \mathrm{ml}$. Cells were plated onto sterile glass coverslips coated with murine collagen $\left(2.5 \mu \mathrm{g} / \mathrm{ml}\right.$, Falcon/BD) in a $35 \mathrm{~mm}$ culture dish. The cells were then cultured at $37^{\circ} \mathrm{C}$ in a $95 \% \mathrm{O}_{2}-5 \% \mathrm{CO}_{2}$ incubator in a smooth muscle growth medium (SMGM, Clonetics Corp., San Diego, CA, U.S.A.) supplemented with $2 \%$ antibiotics/antimycotics (Gibco, Grand Island, NY, U.S.A.) and murine stem cell factor (SCF, $5 \mathrm{ng} / \mathrm{ml}$, Sigma). ICCs were identified immunologically with anti-c-kit antibody (phycoerythrin (PE)-conjugated rat anti-mouse c-kit monoclonal antibody; eBioscience, San Diego, CA, USA) at a dilution of 1:50 for 20 min [31]. The morphologies of ICC were distinct from other cell types in the culture, so it was possible to identify the cells with a phase contrast microscopy once the cells had been confirmed with anti-c-kit antibody.

\section{Patch-clamp experiments}

The physiological salt solution used to bathe cells $\left(\mathrm{Na}^{+}\right.$-Tyrode) contained (mM): $\mathrm{KCl} 5, \mathrm{NaCl} 135$, $\mathrm{CaCl}_{2} 2$, glucose $10, \mathrm{MgCl}_{2} 1.2$ and HEPES 10 , adjusted to $\mathrm{pH} 7.4$ with $\mathrm{NaOH}$. The pipette solution contained (mM): $\mathrm{KCl}$ 140, $\mathrm{MgCl}_{2} 5, \mathrm{~K}_{2}$ ATP 2.7, NaGTP 0.1, creatine phosphate disodium 2.5, HEPES 5 and EGTA 0.1, adjusted to $\mathrm{pH} 7.2$ with $\mathrm{KOH}$. The whole-cell configuration of the patch-clamp technique was used to record membrane potentials (current clamp) of cultured ICC. Axopatch I-D (Axon Instruments, Foster, CA, USA.) amplified membrane currents and potentials. The command pulse was applied using an IBM-compatible personal computer and pClamp software (version 6.1; Axon Instruments). The data were filtered at $5 \mathrm{kHz}$ and displayed on an oscilloscope, a computer monitor and with a pen recorder (Gould 2200, Gould, Valley view, OF, USA.). Results were analyzed using pClamp and Origin (version) software. All experiments were performed at $30^{\circ} \mathrm{C}$.

\section{RT-PCR with c-Kit positive cell and smooth muscle cell}

First, we identified the c-Kit positive cells with under a confocal laser scanning microscope and then single cell with c-Kit positive was collected by applying negative pressure to a cell in contact with recording pipette, lifting the cell out of the bath, and immediately single cell was expelled from the pipette into PCR tube, which contained lysis buffer. Total RNA was extracted by using TRIzol reagent (Invitrogen), and reverse transcription of total RNA was performed by using random hexamer primers and Superscript II-RT (Life Technologies Inc), according to the manufacturer's instructions. Primers used as follows : ET $_{\mathrm{A}}$ (Accession number NM_010332), forward 5' - CCC AAA ACC TCC CAA GTC TCT C - 3', reverse 5' - TGG AAA TGA CAT GCG CGG TAT - 3', (with a product size of 159 bp)-; ET $_{\text {В }}$ (Accession number NM_007904), forward 5' - CCC TTC ACC TCA GCC GGA TCC T - 3', reverse 5' - GGC ACC AGC AGC ACA AAC ATG A - 3', (with a product size of 203 bp)-; c-kit (Accession number Y00864), forward 5' - CAC TGT CCA ACA TAA AGG GT - 3', reverse 5' - GGA AAG GTG CAA GAG TGT AG - 3', (with a product size of 179 bp), myosin (Accession number NM_010860), forward 5' - GAG ATG AAT GTG AAG GTG CT -3', reverse 5' - CTT CCT CTG TCA TCT TCT CG - 3', (with a product size of 195 bp), and PGP9.5 (Accession number AF172334), forward 5' - AAA GCA AAT TGA GGA ACT GA - 3', reverse 5' - GTT CTT CTC GAA ACA CTT GG - 3', (with a product size of $216 \mathrm{bp}$ ). Primers were performed for 40 cycles under the following conditions: denaturing at $94^{\circ} \mathrm{C}$ for 2 minutes, annealing at $50^{\circ} \mathrm{C}$ for 1 minute, and polymerization at $72^{\circ} \mathrm{C}$ for 1 minute. The identification of the PCR products was confirmed by DNA sequencing.

\section{Immunohistochemistry}

Cultured ICCs from small intestine of Balb/C were used for immunohischemistry. Cultured ICCs were fixed in cold acetone $\left(4^{\circ} \mathrm{C}\right)$ for $5 \mathrm{~min}$. After fixation, they were washed in phosphate-buffered saline (PBS; $0.01 \mathrm{M}, \mathrm{pH} 7.4$ ) and immersed in $0.3 \%$ Triton X-100 in PBS. After blocking with $1 \%$ bovine serum albumin (BSA; Sigma) in $0.01 \mathrm{M}$ PBS for 1 hour at room temperature, they were incubated with a goat antibody raised against c-Kit (R\&D systems, Inc) at $4 \mu \mathrm{g} / \mathrm{ml}$, or rabbit antibody against VPAC1 and VPAC2 (Santa cruz) for 24 hours $\left(4^{\circ} \mathrm{C}\right.$ ). After rinse in PBS at $4^{\circ} \mathrm{C}$, they were labeled with the donkey anti-goat Alexa Fluro 568 (Molecular 


\begin{tabular}{|c|c|c|}
\hline Coll & Cell Physiol Biochem 2012;30:359-371 & \\
\hline and Biochemistry & $\begin{array}{l}\text { DOI: 10.1159/0000339070 } \\
\text { Published online: June 29, } 2012\end{array}$ & $\begin{array}{l}\text { (c) } 2012 \text { S. Karger AG, Basel } \\
\text { www.karger.com/cpb }\end{array}$ \\
\hline & ET on I & \\
\hline
\end{tabular}

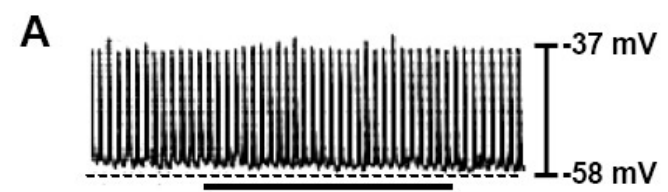

ET-1 $1 \mathrm{nM}$

C

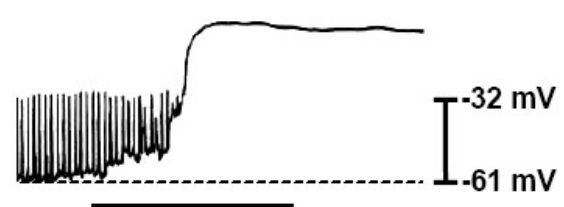

ET-1 $30 \mathrm{nM}$
B

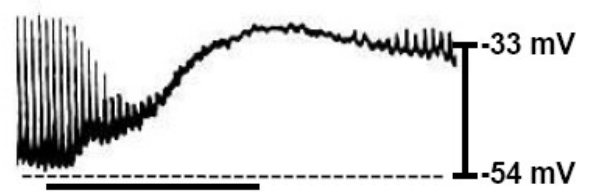

ET-1 $10 \mathrm{nM}$

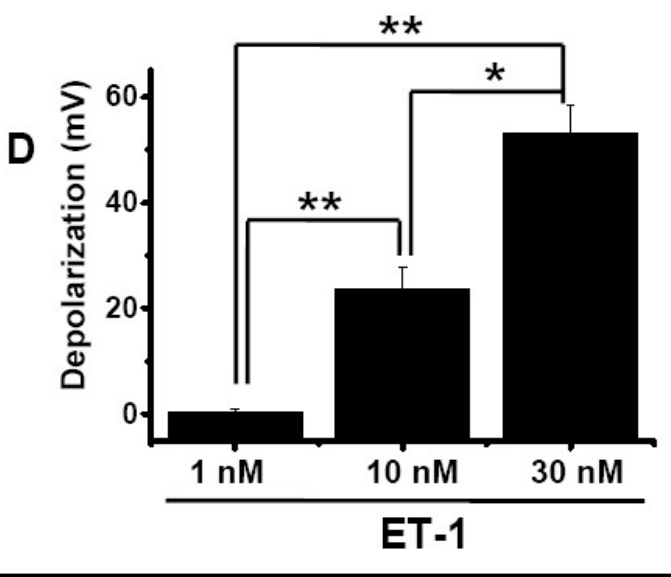

Fig. 1. Effects of endothelin (ET)-1 on pacemaker potentials in cultured ICC of the murine small intestine. (A-C) Pacemaker potentials from ICC exposed to ET-1 (1-30 nM) in the current-clamp mode (I=0). ET-1 caused a concentration-dependent membrane depolarization and decreased the frequency and amplitude of pacemaker potentials. Responses to ET- 1 are summarized in (D). Bars represent mean values \pm S.E. $* P<0.05$, ${ }^{* *} P<0.01$ : significantly different from the untreated control. The dotted lines indicate zero current levels.

Probe, $1 \mu \mathrm{g} / \mathrm{ml}$, red color) or donkey anti-rabbit Alexa Fluro 488 (Molecular Probe, $1 \mu \mathrm{g} / \mathrm{ml}$, green color) for $1 \mathrm{~h}$ at room temperature. For double immunostaining, specimens were incubated with a mixture of antibody raised against VPAC1 or VPAC2 and antibody raised against c-kit for $24 \mathrm{~h}$ at $4{ }^{\circ} \mathrm{C}$. After a through wash with PBS, the mixture of labeled secondary antibodies was incubated for $1 \mathrm{~h}$ at room temperature. Tissues were examined with laser scanning confocal microscope (FV 300, Olympus, Japan) with an excitation wavelength appropriate for Alexa Fluro (568 nm or $488 \mathrm{~nm}$ ). Final images were constructed with Flow-View software (Olympus, Japan).

\section{Statistics}

All data are expressed as mean \pm S.E. Student's t-test for unpaired data was used to compare the control and the experimental groups. A $P$ value of less than 0.05 was considered to indicate statistically significant differences. The $\mathrm{n}$ values reported in the text refer to the number of cells used in experiments.

\section{Results}

\section{Effects of endothelin (ET)-1 on pacemaker potentials in cultured ICCs of the murine small} intestine

Under a current clamp mode $(I=0)$, ICC generated pacemaker potentials. The resting membrane potential was $-58 \pm 3 \mathrm{mV}$ and amplitude was $22 \pm 3 \mathrm{mV}$. ET- $1(1-30 \mathrm{nM})$ produced membrane depolarization and decreased the frequency and amplitude of pacemaker potentials in a concentration-dependent manner (Fig. 1A-C). The addition of ET-1 $1 \mathrm{nM}$, there are no any responses (Fig. 1A). But, in the presence of ET-1 $10 \mathrm{nM}$ or $30 \mathrm{nM}$, membrane depolarizations were $23.6 \pm 2 \mathrm{mV}$ and $53.1 \pm 3 \mathrm{mV}$, respectively (Fig. $1 \mathrm{~B}$ and $1 \mathrm{C}, \mathrm{n}=7$ ). The summarized values and bar graph of ET- 1 effects on pacemaker potentials are shown in Fig. 1D. These results suggest that ET-1 modulated pacemaker activity in a dose-dependent manner in ICCs. 


\begin{tabular}{|c|c|c|}
\hline \multirow{3}{*}{$\begin{array}{l}\text { Cellular Physiolosy } \\
\text { and Biochemistry }\end{array}$} & \multirow{2}{*}{$\begin{array}{l}\text { Cell Physiol Biochem 2012;30:359-371 } \\
\text { DOI: 10.1159/000339070 }\end{array}$} & \\
\hline & & $\begin{array}{l}\text { (c) } 2012 \text { S. Karger AG, Basel } \\
\text { www.karger.com/cpb }\end{array}$ \\
\hline & Kim/Chang/So: Role of ET on ICCs & \\
\hline
\end{tabular}

Fig. 2. A comparison of the concentration-dependent membrane depolarization to ET-1, ET-2 and ET-3. (A, B) Pacemaker potentials from ICC exposed to ET-2 (10 nM) and ET-3 $(10 \mathrm{nM})$ in the currentclamp mode ( $\mathrm{I}=0)$. ET-2 and ET-3 caused a concentrationdependent membrane depolarization and decreased the frequency and amplitude of pacemaker potentials. (C) Responses to ET are summarized. Each point represents the means with the S.E. shown by vertical bars. ${ }^{* *}$ Asterisks are significantly different from the control $(\mathrm{p}<$ 0.01 ). Dotted lines indicate zero current levels.

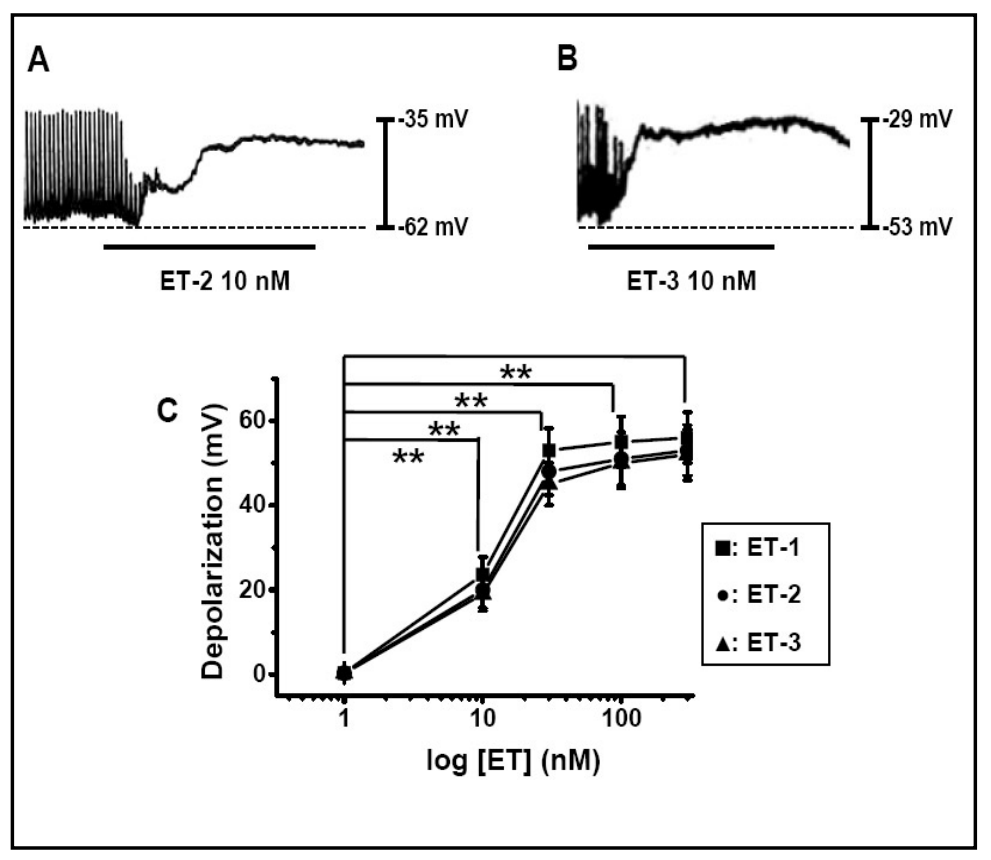

Fig. 3. Effects of $\operatorname{GDP}_{\beta} \mathrm{S}$ on the response to ET-1. (A) Pacemaker potentials of ICCs exposed to ET-1 $(10 \mathrm{nM})$ in the presence of $\mathrm{GDP}_{\beta} \mathrm{S}(1 \mathrm{mM})$ in the pipette. $\mathrm{GDP}_{\beta} \mathrm{S}$ partially blocked the ET-1 mediated membrane depolarization of pacemaker potentials. The effect of ET-1 in the presence of $\mathrm{GDP}_{\beta} \mathrm{S}$ but not in the pipette is summarized in (B) and (C). Bars represent mean values \pm S.E.

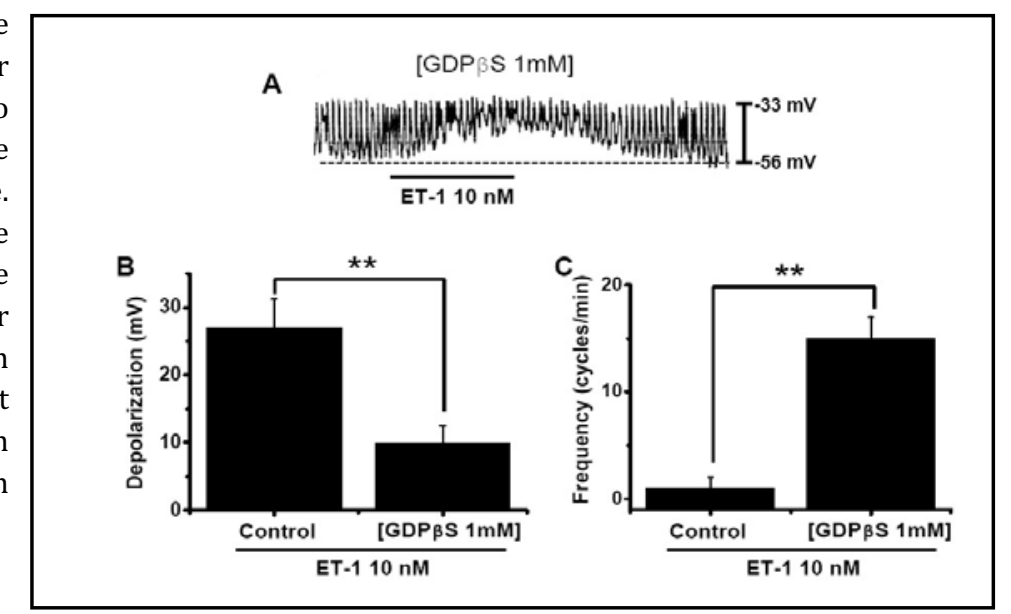

A comparison of the concentration-dependent membrane depolarization to ET-1, ET-2 and ET-3

We compared the effects of three different ET types on pacemaker potentials in cultured ICCs. ET-2 and ET-3 (1-30 nM) also produced membrane depolarization and decreased the frequency and amplitude of pacemaker potentials in a concentration-dependent manner (Fig. 2A and 2B, $\mathrm{n}=8$ ). In the presence of ET-1, ET-2 and ET-3, membrane depolarizations were $23.5 \pm 4 \mathrm{mV}, 20.1 \pm 4 \mathrm{mV}$ and $19.1 \pm 3$ at $10 \mathrm{nM} ; 53.2 \pm 5 \mathrm{mV}, 48.1 \pm 5 \mathrm{mV}$ and $45.2 \pm$ 3 at $30 \mathrm{nM} ; 55.1 \pm 5 \mathrm{mV}, 51.2 \pm 4 \mathrm{mV}$ and $50.2 \pm 4$ at $100 \mathrm{nM} ; 56.2 \pm 5 \mathrm{mV}, 53.1 \pm 4 \mathrm{mV}$ and $52.0 \pm 5$ at $300 \mathrm{nM}$, respectively. The summarized values of ET-1, ET-2 and ET-3 effects on pacemaker potentials are shown in Fig. 2C.

Involvement of G-proteins in ET-1 induced membrane depolarization of pacemaker potentials

The effects of $\mathrm{GDP}_{\beta} \mathrm{S}$, a nonhydrolysable guanosine 5'-di-phosphate analogue, which permanently inactivates GTP-binding proteins [32], were examined to determine whether the G-protein is involved in the effects of ET-1 in ICCs. The effect of ET-1 was reduced when $\mathrm{GDP}_{\beta} \mathrm{S}(1 \mathrm{mM})$ was in the pipette (Fig. 3A). Under control conditions, the addition of ET-1 $(10 \mathrm{nM})$ caused the membrane depolarization and decreased the frequency on pacemaker potentials (membrane depolarization: $27.1 \pm 4 \mathrm{mV}$; frequency: $1.1 \pm 1$ cycles $\mathrm{min}^{-1}$ ). In the 


\begin{tabular}{|c|c|c|}
\hline Coll & Cell Physiol Biochem 2012;30:359-371 & \\
\hline and Biochemistry & $\begin{array}{l}\text { DOI: 10.1159/0000339070 } \\
\text { Published online: June 29, } 2012\end{array}$ & $\begin{array}{l}\text { (c) } 2012 \text { S. Karger AG, Basel } \\
\text { www.karger.com/cpb }\end{array}$ \\
\hline & ET on I & \\
\hline
\end{tabular}

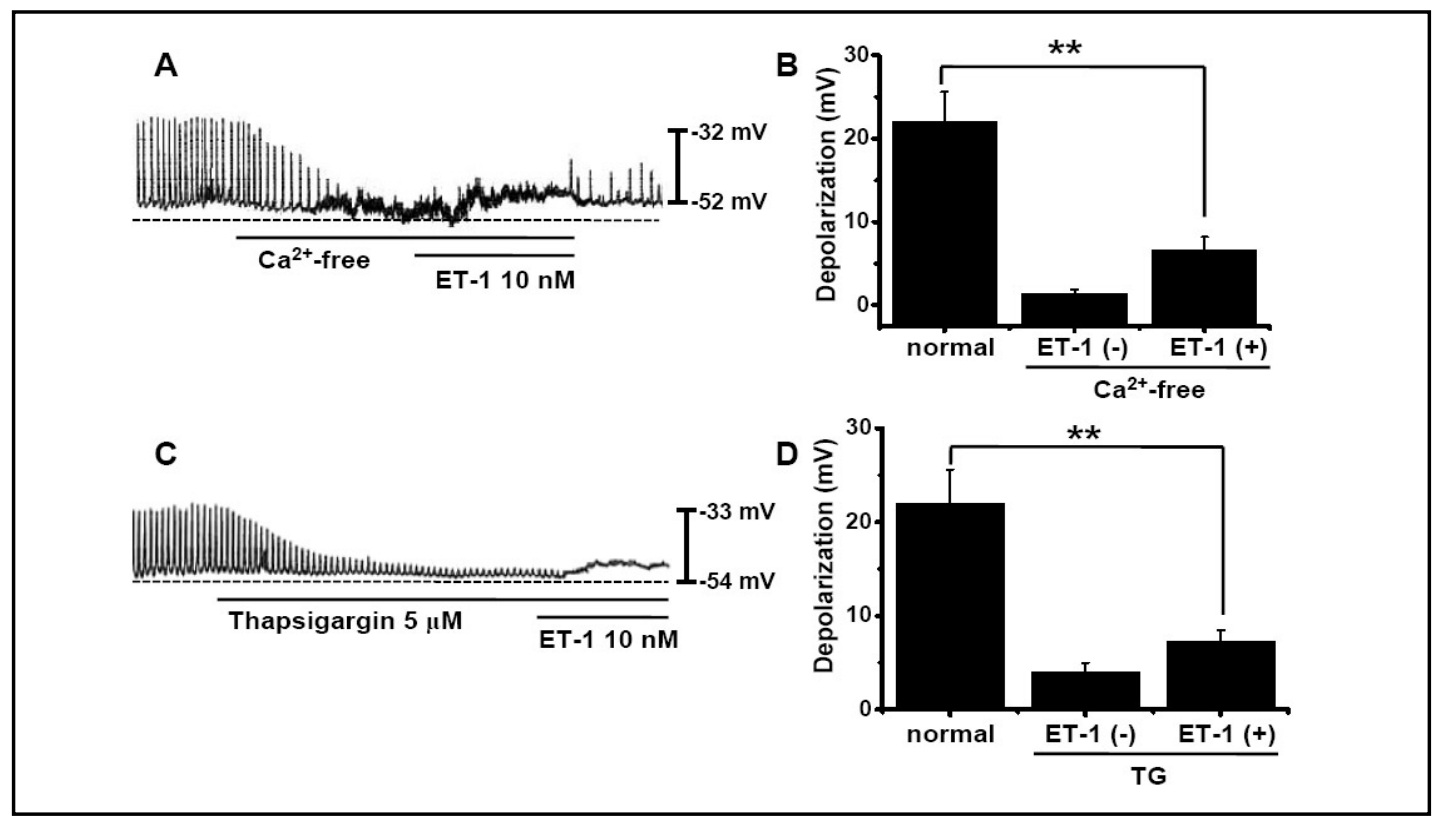

Fig. 4. Effects of an external $\mathrm{Ca}^{2+}$-free solution and thapsigargin upon ET-1 induced responses on pacemaker potentials in cultured ICCs of the murine small intestine. (A) The external $\mathrm{Ca}^{2+}$-free solution abolished the generation of pacemaker potentials. Under this condition, ET-1 induced depolarizations were suppressed. (C) Thapsigargin $(5 \mu \mathrm{M})$ abolished the generation of pacemaker potentials. However, thapsigargin blocked the ET-1 induced depolarization. Responses to ET-1 in the external $\mathrm{Ca}^{2+}$-free solution and in the presence of thapsigargin are summarized in (B) and (D). Bars represent mean values \pm S.E. ${ }^{* *}$ Asterisks are significantly different from the control $(\mathrm{p}<0.01)$. Dotted lines indicate zero current levels.

presence of $\mathrm{GDP}_{\beta} \mathrm{S}$ in the pipette, the effects of ET- 1 on these variables were attenuated; the membrane depolarization and frequency were $10.2 \pm 2 \mathrm{mV}$ and $15.1 \pm 2$ cycles $\mathrm{min}^{-1}$, respectively ( $n=5$ ) (Fig. 3B and 3C). These values were significantly different from those obtained with ET-1 alone. This indicates that G-proteins have an essential role in ET-1 induced effects on pacemaker potentials in ICCs.

Effects of external $\mathrm{Ca}^{2+}$-free solution and $\mathrm{Ca}^{2+}$-ATPase inhibitor of endoplasmic reticulum in ET-1 induced responses in cultured ICCs

To investigate the role of external $\mathrm{Ca}^{2+}$ or internal $\mathrm{Ca}^{2+}$, ET- 1 was tested under external $\mathrm{Ca}^{2+}$-free conditions and in the presence of thapsigargin, a $\mathrm{Ca}^{2+}$-ATPase inhibitor of endoplasmic reticulum. Pacemaker potentials were completely abolished by external $\mathrm{Ca}^{2+}-$ free solution. In this condition, ET- 1 induced membrane depolarizations were suppressed (n = 5; Fig. 4A). In the external $\mathrm{Ca}^{2+}$-free solution, the membrane depolarizations produced by ET-1 were $6.7 \pm 2 \mathrm{mV}$. These values were significantly different when compared with ET-1 in normal $\mathrm{Ca}^{2+}$ solution (Fig. 4B). In addition, ET-1 induced membrane depolarizations were suppressed with pretreatment of thapsigargin ( $\mathrm{n}=5$; Fig. 4C). In the presence of thapsigargin $(5 \mu \mathrm{M})$, the membrane depolarizations produced by ET- 1 were $7.3 \pm 1 \mathrm{mV}$. These values were significantly different when compared to ET-1 in the absence of thapsigargin (Fig. 4D).

\section{Effects of protein kinase C inhibitor or cyclooxygenase inhibitor in ET1-induced responses} in cultured ICCs

We tested the effects of chelerythrine and calphostin $\mathrm{C}$ or naproxen to investigate whether ET-1 induced responses to pacemaker potentials are mediated by the activation of protein kinase $\mathrm{C}$ or the production of prostaglandins. Chelerythrine $(1 \mu \mathrm{M})$, calphostin $\mathrm{C}(1$ $\mu \mathrm{M})$ and naproxen $(10 \mu \mathrm{M})$ did not have an effect on pacemaker potentials $(n=5$; Fig. $5 \mathrm{~A}-\mathrm{C})$. Pretreatment with chelerythrine, calphostin $\mathrm{C}$ and naproxen did not block the ET-1 induced membrane depolarizations of pacemaker potentials (Fig. 5D). 


\begin{tabular}{|c|c|c|}
\hline $\mathrm{Col}$ & Cell Physiol Biochem 2012;30:359-371 & \\
\hline and Biochemistry & $\begin{array}{l}\text { DOI: 10.1159/000339070 } \\
\text { Published online: June 29, } 2012\end{array}$ & $\begin{array}{l}\text { (c) } 2012 \text { S. Karger AG, Basel } \\
\text { www.karger.com/cpb }\end{array}$ \\
\hline & n ICCs & \\
\hline
\end{tabular}

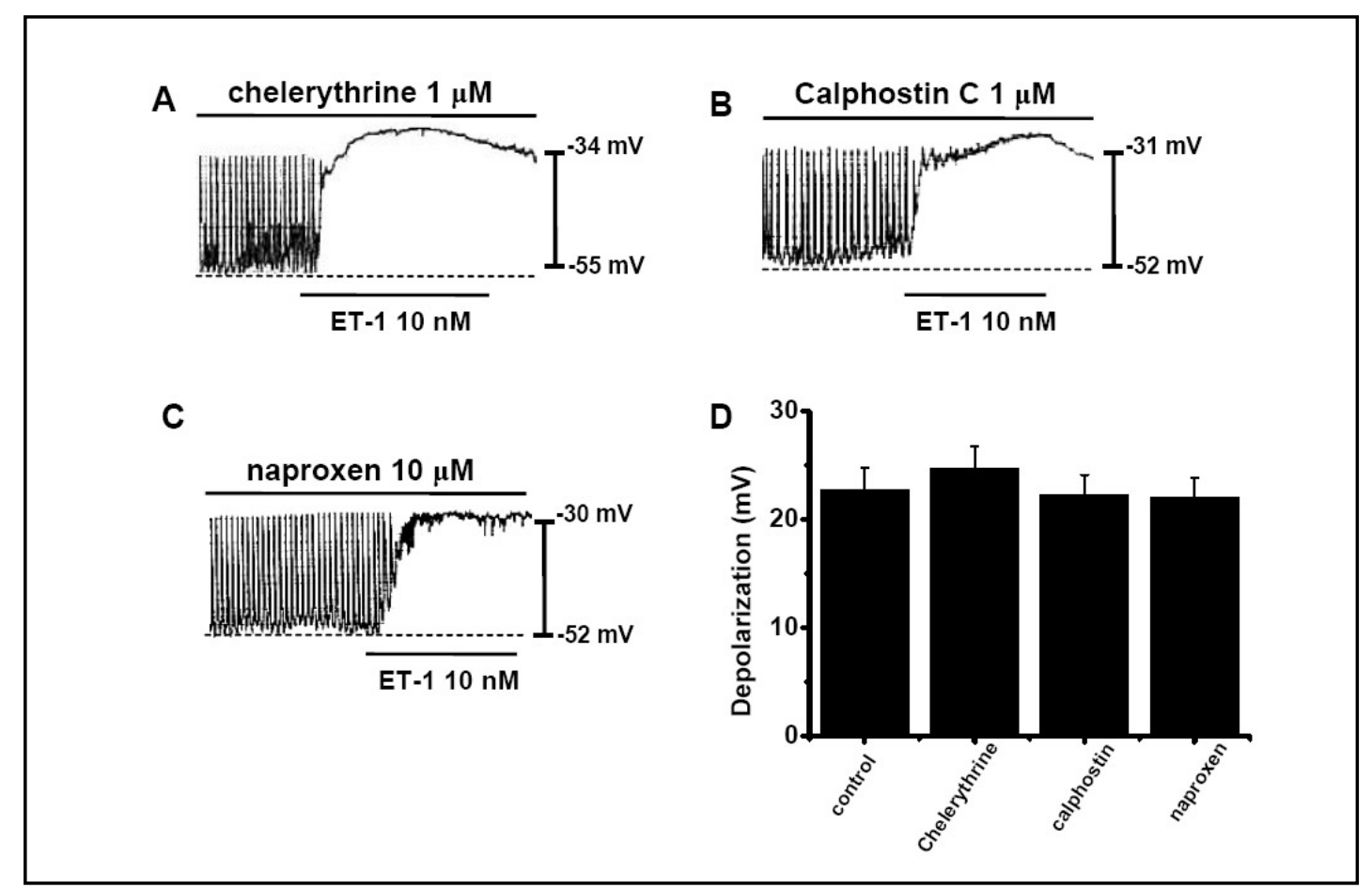

Fig. 5. Effects of chelerythrine, calphostin $C$ (protein kinase $C$ inhibitors) or naproxen (a cyclooxygenase inhibitor) upon ET-1 induced depolarizations on pacemaker potentials in cultured ICC of the murine small intestine. (A, B) Pacemaker potentials of ICC exposed to ET-1 (10 nM) in the presence of chelerythrine (1 $\mu \mathrm{M})$ or calphostin $\mathrm{C}(1 \mu \mathrm{M})$. In this condition, ET-1 caused membrane depolarization and decreased the frequency and amplitude of pacemaker potentials. (C) Pacemaker potentials of ICC exposed to ET-1 (10 nM) in the presence of naproxen $(10 \mu \mathrm{M})$. Naproxen did not block the effects of ET-1 on pacemaker potentials. Responses to ET-1 in the presence of chelerythrine, calphostin C or naproxen are summarized in (D). Bars represent mean values \pm S.E. The dotted lines indicate the zero current levels.

\section{Identification of receptor subtypes of ET-1 in cultured ICCS}

To identify the receptor subtypes of ET, ET receptor antagonists and agonists were used. $\mathrm{ET}_{\mathrm{A}}$ receptor antagonist, $\mathrm{BQ}-123(1 \mu \mathrm{M})$ or $\mathrm{ET}_{\mathrm{B}}$ receptor antagonist, $\mathrm{BQ}-788(1 \mu \mathrm{M})$ itself had no effect on pacemaker potentials. In the presence of BQ-123, ET-1 induced responses on pacemaker potentials in cultured murine small intestinal ICCs were completely blocked ( $\mathrm{n}=$ 5; Fig. 6A). Also, BQ-788 almost completely blocked the ET-1 induced responses to pacemaker potentials $(\mathrm{n}=5$; Fig. $6 \mathrm{~B}$ ). Under controlled conditions, the membrane depolarizations on pacemaker potentials in cultured murine small intestinal ICCs produced by ET- 1 were 23.6 $\pm 3 \mathrm{mV}$ (Fig. 1B). In the presence of BQ-123, the membrane depolarizations on pacemaker potentials produced by ET- 1 were $3.1 \pm 2 \mathrm{mV}$. Also in the presence of BQ-788, the membrane depolarizations on pacemaker potentials produced by ET-1 were $3.3 \pm 2 \mathrm{mV}$. The values of $\mathrm{ET}_{\mathrm{A}}$ receptor antagonist, $\mathrm{BQ}-123$ or $\mathrm{ET}_{\mathrm{B}}$ receptor antagonist, $\mathrm{BQ}-788$ were significantly different from those obtained in controlled conditions (Fig. 6F). We also investigated which receptor subtypes of ET were involved on pacemaker potentials in cultured murine large intestinal ICCs. BQ-123 $(1 \mu \mathrm{M})$ or BQ-788 $(1 \mu \mathrm{M})$ itself had no effect on pacemaker potentials, too. In the presence of BQ-123, ET- 1 induced responses on pacemaker potentials in cultured murine large intestinal ICCs were completely blocked $(n=5$; Fig. 6C). However, surprisingly, in the presence of $\mathrm{ET}_{\mathrm{B}}$ receptor antagonist, BQ-788, ET-1 induced membrane depolarizations on pacemaker potentials were still present $(n=5$; Fig. 6D). Under controlled conditions, the membrane depolarizations on pacemaker potentials in cultured murine large intestinal ICCs produced by ET- 1 were $24.3 \pm 3 \mathrm{mV}$. In the presence of BQ-123, the membrane depolarizations on pacemaker potentials produced by ET-1 were $4.1 \pm 1 \mathrm{mV}$ 


\begin{tabular}{|c|c|c|}
\hline Call & Cell Physiol Biochem 2012;30:359-371 & \\
\hline and Biochemistry & $\begin{array}{l}\text { DOI: 10.1159/000339070 } \\
\text { Published olline: June 29, } 2012\end{array}$ & $\begin{array}{l}\text { (c) } 2012 \text { S. Karger AG, Basel } \\
\text { www.karger.com/cpb }\end{array}$ \\
\hline
\end{tabular}

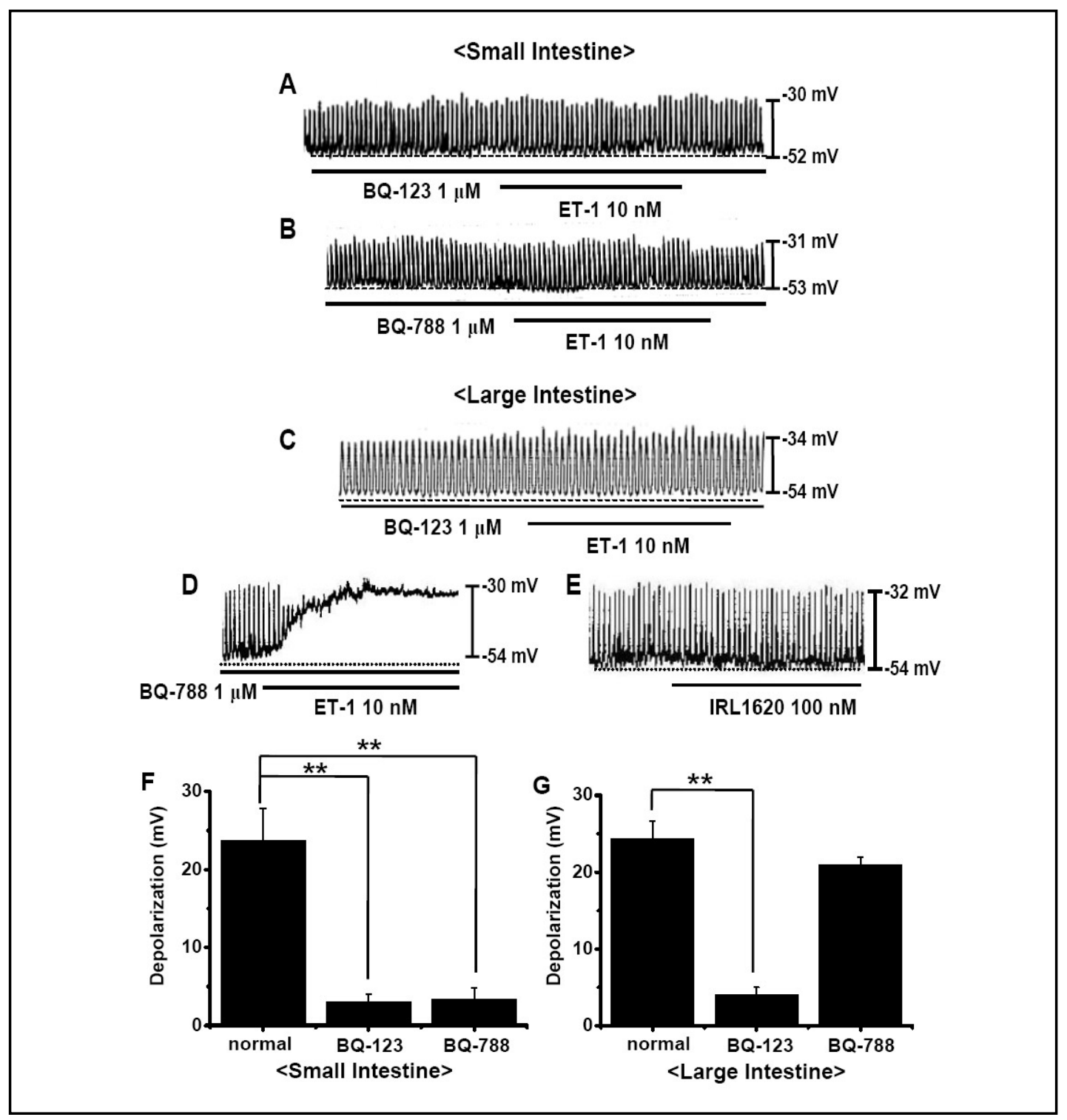

Fig. 6. Effects of ET antagonists on ET-1 induced responses or selective $\mathrm{ET}_{\mathrm{B}}$ receptor agonist on pacemaker potentials in cultured ICC of the murine small and large intestine. (A) Pacemaker potentials of ICC in murine small intestine exposed to ET-1 (10 nM) in the presence of ET $_{A}$ receptor antagonist, BQ-123 (1 $\left.\mu \mathrm{M}\right)$. BQ-123 blocked the effects of ET-1 on pacemaker potentials. (B) Pacemaker potentials of ICC in murine small intestine exposed to ET-1 (10 nM) in the presence of $\mathrm{ET}_{\mathrm{B}}$ receptor antagonist, BQ-788 $(1 \mu \mathrm{M})$. BQ-788 also blocked the effects of ET-1 on pacemaker potentials. (C) Pacemaker potentials of ICC in murine large intestine exposed

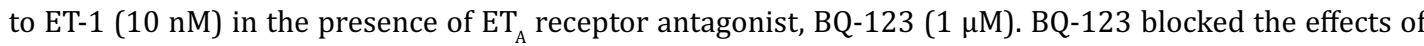
ET-1 on pacemaker potentials. (D) Pacemaker potentials of ICC in murine large intestine exposed to ET-1 $(10 \mathrm{nM})$ in the presence of $\mathrm{ET}_{\mathrm{B}}$ receptor antagonist, BQ-788 $(1 \mu \mathrm{M})$. In the presence of BQ-788, ET-1 still caused membrane depolarization and decreased in the frequency and amplitude of pacemaker potentials. (E) Pacemaker potentials of ICC in murine large intestine exposed to the selective ET B $_{\mathrm{B}}$ receptor agonist, IRL 1620 (100 nM). The selective $\mathrm{ET}_{\mathrm{B}}$ receptor agonist, IRL 1620 did not have any influence on pacemaker potentials. Responses to ET-1 are summarized in $(\mathrm{F}, \mathrm{G})$. Bars represent mean values \pm S.E. ${ }^{* *}$ Asterisks are significantly different from the control $(\mathrm{p}<0.01)$. Dotted lines indicate zero current levels.

(Fig. 6C). However, in the presence of BQ-788, the membrane depolarizations on pacemaker potentials produced by ET- 1 were $21.3 \pm 2 \mathrm{mV}$ (Fig. 6D). The values of ET $_{A}$ receptor antagonist, BQ-123 were significantly different from those obtained in controlled conditions (Fig. 6G). 


\begin{tabular}{|c|c|c|}
\hline Coll & Cell Physiol Biochem 2012;30:359-371 & \\
\hline and Biochemistry & $\begin{array}{l}\text { DOI: 10.1159/0000339070 } \\
\text { Published online: June 29, } 2012\end{array}$ & $\begin{array}{l}\text { (c) } 2012 \text { S. Karger AG, Basel } \\
\text { www.karger.com/cpb }\end{array}$ \\
\hline & ET on I & \\
\hline
\end{tabular}

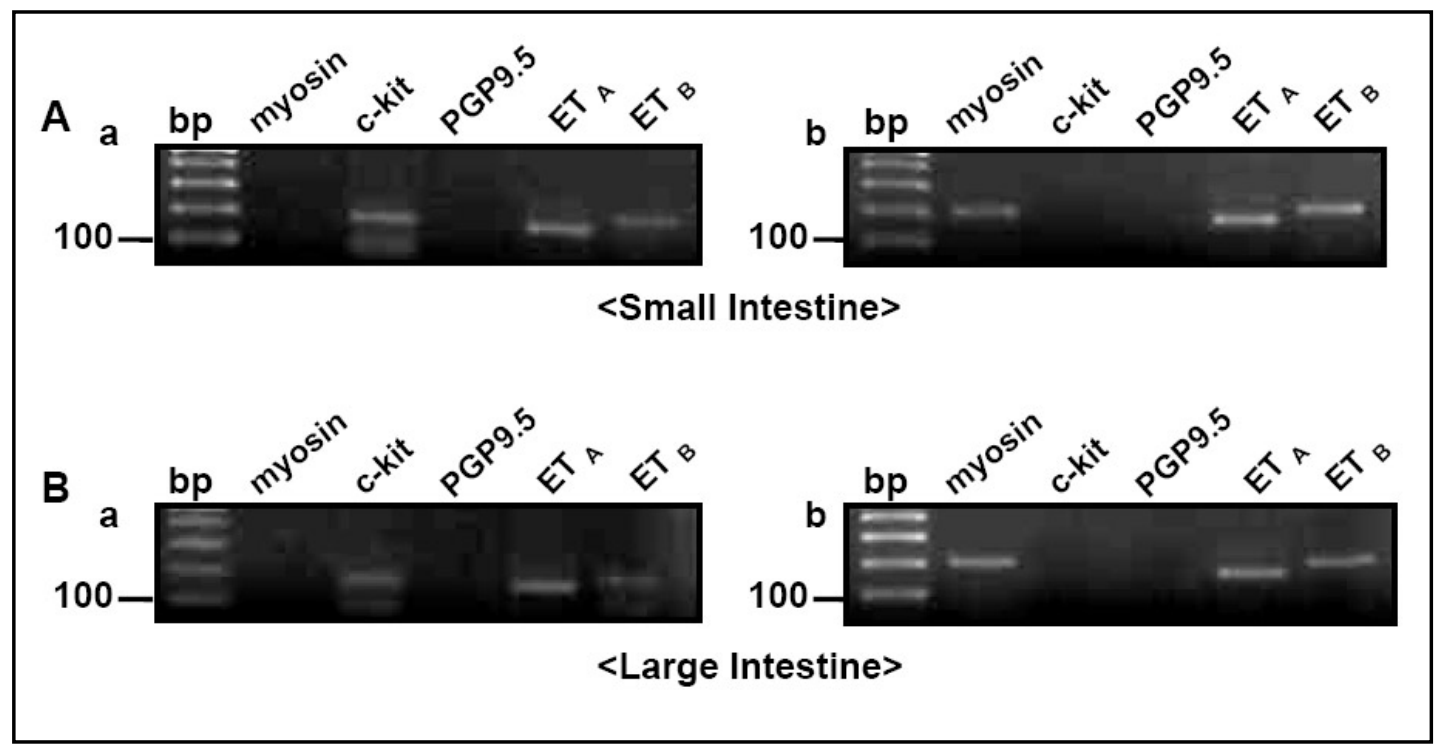

Fig. 7. RT-PCR detection of ET receptor type in single ICC and smooth muscle. Gel electrophoresis of RT-PCR product from single ICC (Aa, $\mathrm{Ba}$ ) and myocyte $(\mathrm{Ab}, \mathrm{Bb})$. RT-PCR product were resolved on $2 \%$ agarose gel and visualized by ethidium bromide staining. Size markers were used to indicate the size of the experimental fragments (lane 1). RT-PCR detection of myosin (smooth muscle marker; $195 \mathrm{bp}$ ), c-kit (ICC marker; $179 \mathrm{bp}$ ), protein gene product 9.5 (PGP 9.5, a pan-neural marker; $216 \mathrm{bp}$ ), $\mathrm{ET}_{\mathrm{A}}$ receptor (159 bp), and $\mathrm{ET}_{\mathrm{B}}$ receptor (203 bp) in mRNAs from mouse intestinal single ICC and smooth muscle cell. (A) Single small intestinal ICC (a) and myocyte (b) show RT-PCR fragments for both $\mathrm{ET}_{\mathrm{A}}\left(159 \mathrm{bp}\right.$ ) and $\mathrm{ET}_{\mathrm{B}}(203 \mathrm{bp}$ ) receptor. (B) Single large intestinal ICC (a) and myocyte (b) show RT-PCR fragments for both $\mathrm{ET}_{\mathrm{A}}(159 \mathrm{bp})$ and $\mathrm{ET}_{\mathrm{B}}(203 \mathrm{bp})$ receptor.

To verify these results, we also used the selective $\mathrm{ET}_{\mathrm{B}}$ receptor agonist, IRL 1620. Under the pacemaker potentials in cultured murine small intestinal ICCs, IRL 1620 caused membrane depolarizations on pacemaker potentials (data not shown). However, under the pacemaker potentials in cultured murine large intestinal ICCs, IRL 1620 did not show any influence on pacemaker potentials (Fig. 6E). These results suggested that ET-1 modulates pacemaker potentials through $\mathrm{ET}_{\mathrm{A}}$ and $\mathrm{ET}_{\mathrm{B}}$ receptor activation in murine small intestinal ICCs and $\mathrm{ET}_{\mathrm{A}}$ receptor activation in murine large intestinal ICCs.

The molecular expression and localization of ET receptor subtypes in ICC

To determine the presence of ET receptor subtypes in murine small intestine, RT-PCR with c-kit positive single cell was performed using $\mathrm{ET}_{\mathrm{A}}$ and $\mathrm{ET}_{\mathrm{B}}$ receptor genespecific primers in ICC. In case of ICC, the expression of $\mathrm{ET}_{A}$ and $\mathrm{ET}_{B}$ was predominant (Fig. 7Aa). Also, in smooth muscle cell, RT-PCR detected transcripts for $\mathrm{ET}_{\mathrm{A}}$ and $\mathrm{ET}_{\mathrm{B}}$ (Fig. 7Ab). In addition, to determine the presence of ET receptor subtypes in murine large intestine, RT-PCR was performed using $\mathrm{ET}_{\mathrm{A}}$ and $\mathrm{ET}_{\mathrm{B}}$ receptor genespecific primers. In case of ICC and smooth muscle cell, the expression of $\mathrm{ET}_{A}$ and $\mathrm{ET}_{B}$ was predominant, too (Fig. 7Ba and 7Bb). This finding indicate that both $\mathrm{ET}_{\mathrm{A}}$ and $\mathrm{ET}_{\mathrm{B}}$ receptor exist in ICC and smooth muscle cell of murine small and large intestine.

Immunohistochemistry for ETA and ETB receptors in cultured ICCS

Expression of $\mathrm{ET}_{\mathrm{A}}$ and $\mathrm{ET}_{\mathrm{B}}$ receptors were investigated by immunohistochemistry on cultured ICCs. Double staining with anti-c-kit (a marker of ICC) and anti-ET and anti$\mathrm{ET}_{\mathrm{B}}$ receptor antibodies revealed a colocalization of $\mathrm{ET}_{\mathrm{A}}$ and $\mathrm{ET}_{\mathrm{B}}$ receptor and c-kit-like immunoreactivities in cultured ICCs (Fig. 8). 


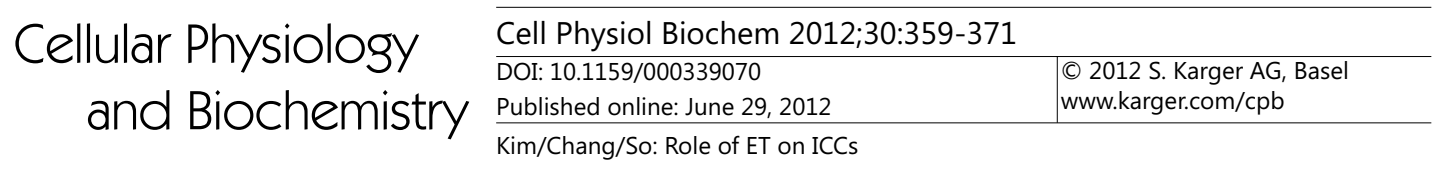

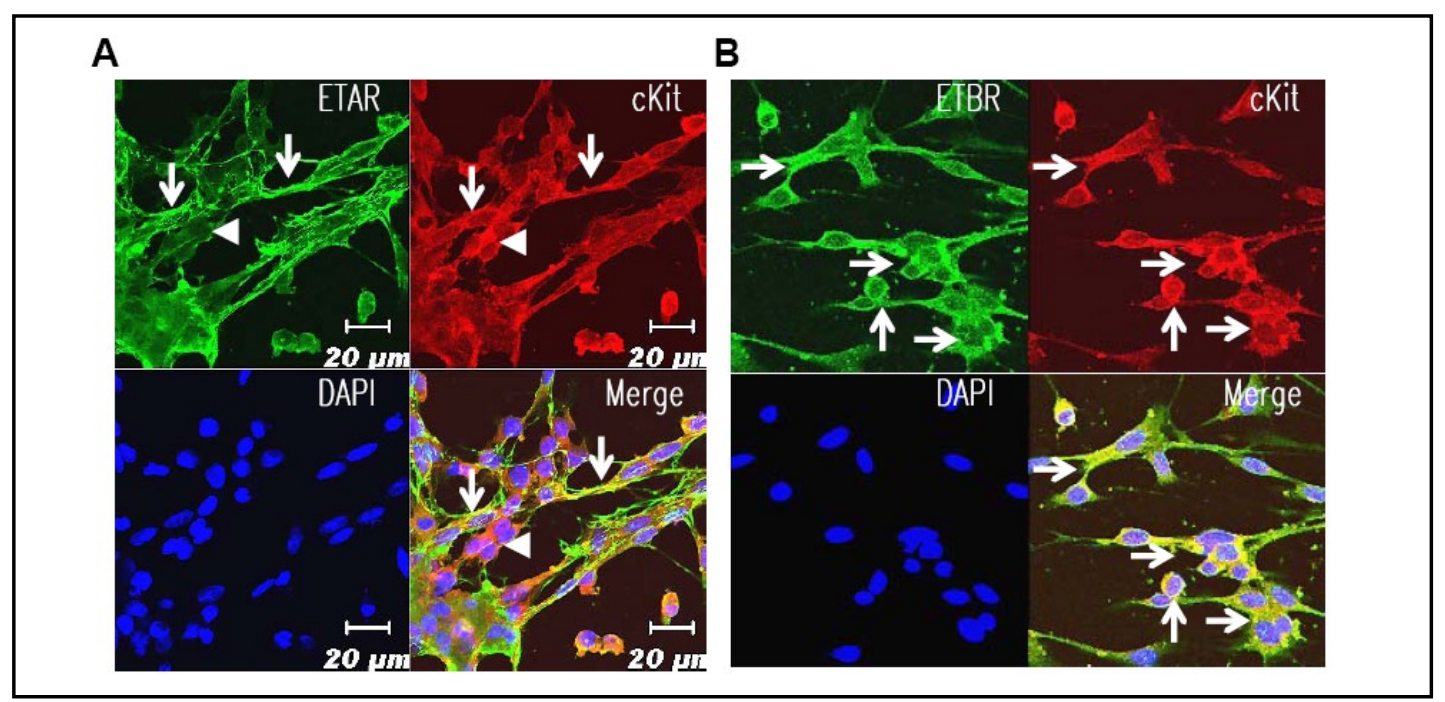

Fig. 8. Expression of $\mathrm{ET}_{\mathrm{A}}$ and $\mathrm{ET}_{\mathrm{B}}$ protein in cultured ICCs. (A) Double-labelling of $\mathrm{ET}_{\mathrm{A}}$-like immunoreactivity (green) and c-kit-like immunoreactivity (red) on cultured ICCs. The mixed color yellow (arrows) indicates the co-localization of both $\mathrm{ET}_{\mathrm{A}}$-like and c-kit-like immunoreactivity. Scale bars: $20 \mu \mathrm{m}$. (B) Double-labelling of $\mathrm{ET}_{\mathrm{B}}$-like immunoreactivity (green) and c-kit-like immunoreactivity (red) on cultured ICCs. Several c-kitlike immunoreactive cell bodies and fibres are colocalized with $\mathrm{ET}_{\mathrm{B}}$-like immunoreactivity (yellow). Scale bars: $20 \mu \mathrm{m}$. Cultured ICCs show co-localization of $\mathrm{ET}_{\mathrm{A}}$ and $\mathrm{ET}_{\mathrm{B}}$ and c-kit-like immunoreactivity.

\section{Discussion}

In the present study, we first demonstrated that ET induces depolarization of the membrane and inhibits pacemaker potentials in intestinal ICC. These effects are mediated through external $\mathrm{Ca}^{2+}$ influx and internal $\mathrm{Ca}^{2+}$ release via protein kinase $\mathrm{C}$-or cyclooxygenaseindependent mechanism.

$\mathrm{ET}_{\mathrm{A}}$ and $\mathrm{ET}_{\mathrm{B}}$ are $\mathrm{G}$ protein-coupled receptors. $\mathrm{ET}_{\mathrm{A}}$ receptorsstimulate phosphatidylinositol turnover $\left(1,4,5\right.$ inositol-phosphate $\left(\mathrm{IP}_{3}\right)$ and diacylglycerol/protein kinase $\left.\mathrm{C}(\mathrm{DAG} / \mathrm{PKC})\right)$, while ETB receptors activate extracellular $\mathrm{Ca}^{2+}$ influx via non-L-type membrane channels, resulting in increased intracellular calcium $\left[\mathrm{Ca}^{2+}{ }_{\mathrm{i}}\right]$. Increased calcium concentrations cause activation of calcium/calmodulin-dependent myosin light-chain kinase (MLCK) and phosphorylation of 20-kDa myosin light chains (MLC), resulting in increased myosin ATPase activity that culminates in smooth muscle contraction [33-36]. In this study, ET induced depolarization of the membrane and inhibition of pacemaker potentials in intestinal ICCs is mediated by the release of 1,4,5-inositol triphosphate (IP ${ }_{3}$ )- dependent intracellular $\mathrm{Ca}^{2+}$ release from endoplasmic reticulum and by external $\mathrm{Ca}^{2+}$ influx. ET causes contraction and relaxation of smooth muscle, electrolyte excretion as well as direct neural effects in many physiologic systems including the cardiovascular, respiratory, GI, genitourinary and central nervous system. ET modulates the vascular tone, heart contraction, tone of airways in the lung, electrolyte excretion in the kidney and circulatory as well as respiratory functions in the brain [13,17, 37-41]. Endothelin receptors are widely expressed in all tissues. Receptors are also localized to non-vascular structures such as epithelial cells as well as occurring in the central nervous system on glial and neurons. Both $\mathrm{ET}_{\mathrm{A}}$ and $\mathrm{ET}_{\mathrm{B}}$ receptors are widely distributed, particularly in blood vessels $[42,43] . \mathrm{ET}_{\mathrm{A}}$ receptors present on smooth muscle cells are mainly responsible for contraction, but in animals this can vary depending on the species and vessels. Many agonists and antagonists have been developed, although selective $\mathrm{ET}_{\mathrm{A}}$ receptor agonists have not been reported to date. In the GI tract, ET causes contraction and/or relaxation of the esophagus, stomach, ileum and colon. ET causes smooth muscle contraction through interaction with $\mathrm{ET}_{\mathrm{A}}$ receptors, $\mathrm{ET}_{\mathrm{B}}$ receptors or both subtypes, depending on tissues and species $[17,44-50]$. Previous studies have shown that ET causes gastrointestinal muscle contraction through interaction with both $\mathrm{ET}_{\mathrm{A}}$ and $\mathrm{ET}_{\mathrm{B}}$ receptors in 


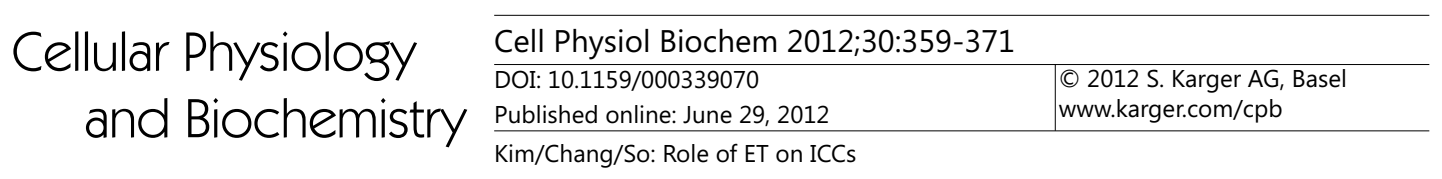

the esophageal muscularis mucosae, gallbladder, ileum, and cecum [44-46]. On the other hand, although the common bile duct muscle and gastric muscle contraction cells possess both $\mathrm{ET}_{\mathrm{A}}$ and $\mathrm{ET}_{\mathrm{B}}$ receptors, only $\mathrm{ET}_{\mathrm{A}}$ receptors mediate contraction $[47,48]$. In addition to contraction, ET causes smooth muscle relaxation through interaction with $\mathrm{ET}_{\mathrm{A}}$ receptors or $\mathrm{ET}_{\mathrm{B}}$ receptors. In the stomach strips, $\mathrm{ET}_{\mathrm{A}}$ receptors mediate relaxation [49]; however, in the ileum strips, $\mathrm{ET}_{\mathrm{B}}$ receptors mediate relaxation [50]. In this study, in the cultured mouse ICCs, both $\mathrm{ET}_{\mathrm{A}}$ and $\mathrm{ET}_{\mathrm{B}}$ mediate the contraction of small intestine, however, only $\mathrm{ET}_{\mathrm{A}}$ mediates the contraction of large intestine.

ICCs serve as the pacemaker cells of the GI tract. ICCs generated the spontaneous pacemaker potentials and conducted the slow waves into the smooth muscle syncytium because ICCs are electrically coupled to neighboring smooth muscle cells. Smooth muscle cells respond to the slow wave depolarization with the activation of L-type $\mathrm{Ca}^{2+}$ channels. Also the smooth muscle response is regulated by neural inputs. Both excitatory and inhibitory enteric motor neurons are closely associated with ICCs. Neural modification of the smooth muscle response, via ICCs, modulates excitation-contraction coupling between slow waves and contractions. Therefore, loss or dysfunction of any part of the ICCs, smooth muscle cells and neurons can result in GI motility disorders [51].

In this study, ET depolarized the pacemaker potential and decreased the frequency and amplitude of pacemaker activity. Generally, if the pacemaker potential in ICCs was depolarized and the frequency and amplitude of pacemaker activity was decreased, ICCs were contracted such as carbachol (CCh) [52]. Therefore, ET could affect the pacemaker activities of ICCs and the consequent contractions of smooth muscle cells. However, the smooth muscle response is also regulated by neural inputs. Therefore, we might consider the ICCs, smooth muscle cells, and neurons on the effect of ET on GI tract. ET might contract or relax on GI tract depending on the animal species, gut segment, the profile of activated receptors and interactions with other mediators acting at target sites [53]. Therefore, we will investigate the effect of ET on ICCs, smooth muscle cells and neurons in mouse intestine in future.

In conclusion, ET-1 modulates pacemaker potentials through $\mathrm{ET}_{\mathrm{A}}$ and $\mathrm{ET}_{\mathrm{B}}$ receptor activation in murine small intestinal ICCs and $\mathrm{ET}_{A}$ receptor activation in murine large intestinal ICCs by external $\mathrm{Ca}^{2+}$ influx and internal $\mathrm{Ca}^{2+}$ release via protein kinase $\mathrm{C}$ or cyclooxygenaseindependent mechanism.

\section{Acknowledegments}

This research was supported by Basic Science Research Program through the National Research Foundation of Korea (NRF) funded by the Ministry of Education, Science and Technology (2010-0021347).

\section{References}

1 Szurszewski JH: Electrical basis for gastrointestinal motility. in: Physiology of the Gastrointestinal Tract (2nd ed.). New York, Raven Press 1987, pp 383-422.

2 Huisinga JD, Thuneberg L, Kluppel M, Malysz J, Mikkelsen HB, Bernstein A: W/kit gene required for intestinal pacemaker activity. Nature 1995;373:347-352.

3 Langton P, Ward SM, Carl A, Nerell MA, Sanders KM: Spontaneous electrical activity of interstitial cells of Cajal isolated from canine proximal colon. Proc Natl Acad Sci USA 1989;86:7280-7284.

4 Ordog T, Ward SM, Sanders KM: Interstitial cells of Cajal generate electrical slow waves in the murine stomach. J Physiol 1999;518:257-269.

5 Sanders KM: A case for interstitial cells of Cajal as pacemakers and mediators of neurotransmission in the gastrointestinal tract. Gastroenterology 1996;111:492-515. 


\begin{tabular}{|c|c|c|}
\hline \multirow{3}{*}{$\begin{array}{c}\text { Cellular Physiolosy } \\
\text { and Biochemistry }\end{array}$} & \multirow{2}{*}{$\begin{array}{l}\text { Cell Physiol Biochem 2012;30:359-371 } \\
\text { DOI: 10.1159/000339070 } \\
\text { Published online: June 29, 2012 }\end{array}$} & \\
\hline & & $\begin{array}{l}\text { O) } 2012 \text { S. Karger AG, Basel } \\
\text { www.karger.com/cpb }\end{array}$ \\
\hline & ple of ET on ICCs & \\
\hline
\end{tabular}

6 Ward SM, Burns AJ, Torihashi S, Sanders KM: Mutation of the proto-oncogene c-kit blocks development of interstitial cells and electrical rhythmicity in murine intestine. J Physiol 1994;480:91-102.

7 Jun JY, Choi S, Yeum CH, Chang IY, Park CK, Kim MY, Kong ID, So I, Kim KW, You HJ: Noradrenaline inhibits pacemaker currents through stimulation of beta 1-adrenoceptors in cultured interstitial cells of Cajal from murine small intestine. Br J Pharmacol 2004;141:670-677.

8 Jun JY, Choi S, Yeum CH, Chang IY, You HJ, Park CK, Kim MY, Kong ID, Kim MJ, Lee KP, So I, Kim KW: Substance P induces inward current and regulates pacemaker currents through tachykinin NK1 receptor in cultured interstitial cells of Cajal of murine small intestine. Eur J Pharmacol 2004;495:35-42.

9 Jun JY, Choi S, Chang IY, Yoon CK, Jeong HG, Kong ID, So I, Kim KW, You HJ: Deoxycholic acid inhibits pacemaker currents by activating ATP-dependent $\mathrm{K}^{+}$channels through prostaglandin E2 in interstitial cells of Cajal from the murine small intestine. Br J Pharmacol 2005;144:242-251.

10 Choi S, Yeum CH, Chang IY, You HJ, Park JS, Jeong HS, So I, Kim KW, Jun JY: Activating of ATP-dependent K ${ }^{+}$ channels comprised of K(ir) 6.2 and SUR 2B by PGE2 through EP2 eceptor in interstitial cells of Cajal from the murine small intestine. Cell Physiol Biochem 2006;18:187-198.

11 Choi S, Park do Y, Yeum CH, Chang IY, You HJ, Park CG, Kim MY, Kong ID, So I, Kim KW, Jun JY: Bradykinin modulates pacemaker currents through bradykinin B2 receptors in cultured interstitial cells of Cajal from the murine small intestine. Br J Pharmacol 2006;148:918-926.

12 Yanagisawa M, Kurihara H, Kimura S, Tomobe Y, Kobayashi M, Mitsui Y, Yazaki Y, Goto K, Masaki T: A novel potent vasoconstrictor peptide produced by vascular endothelial cells. Nature 1988;332:411-415.

13 Masaki T, Vane JR, Vanhoutte PM: International Union of Pharmacology nomenclature of endothelin receptors. Pharmacol Rev 1994;46:137-142.

14 Inoue A, Yanagisawa M, Kimura S: The human endothelin family: three structurally and pharmacologically distinct isopeptides predicted by three separate genes. Proc Natl Acad Sci U S A 1989;86:2863-2867.

15 Turner AJ, Murphy LD: Molecular pharmacology of endothelin converting enzymes. Biochem Pharmacol 1995;51:91-102.

16 Brunner F, Bras-Silva C, Cardeira AS, Leite-Moreira F: Cardiovascular endothelins: essential regulators of cardiovascular homeostasis. Pharmacol Ther 2006;111:508-511.

17 Rubanyi GM, Polokoff MA: Endothelins: molecular biology, biochemistry, pharmacology, physiology and pathophysiology. Pharmacol Rev 1994;46:325-415.

18 Brunner F, Bras-Silva C, Cardeira AS, Leite-Moreira F: Cardiovascular endothelins: essential regulators of cardiovascular homeostasis. Pharmacol Ther 2006;111:508-511.

19 Kuruvilla L, Kartha CC: Molecular mechanisms in endothelial regulation of cardiac function. Mol Cell Biochem 2003;253:113-123.

20 Naicker S, Bhoola KD: Endothelins: vasoactive modulators of renal function in health and disease. Pharmacol Ther 2001;90:61-88.

21 Egidy G, Juillerat-Jenneret C, Korth P, Bosman F, Pinet F: The endothelin system in normal human colon. Am J Physiol 2000;279:G211-222.

22 Sakurai T, Yanagisawa M, Takuwa Y, Miyazaki H, Kimura S, Goto K, Masaki T: Cloning of a cDNA encoding a non-isopeptide-selective subtype of the endothelin receptor. Nature 1990;348:732-735.

23 Zhu L, Lee HO, Jordan CS, Cantrell VA, Southardsmith EM, Shin MK: Spatiotemporal regulation of endothelin receptor-B by SOX10 in neural crest-derived enteric neuron precursors. Nat Genet 2004;36:732-737.

24 Tekin E, Taneri F, Ersoy E, Bozkurt S, Yavuzer R, Ercan S, Oguz M: Ileal and colonic contractions by endothelin-1 in experimentally induced paralytic ileus in rats. Gen Pharmacol 1999;32:631-635.

25 Davenport AP, Maguire JJ: Of mice and men: advances in endothelin research and first antagonist gains FDA approval. Trends Pharmacol Sci 2002;23:155-157.

26 Lin WW, Lee CY: Biphasic effects of endothelin in the guinea-pig ileum. Eur J Pharmacol 1990;176:57-62.

27 Allcock GH, Battistini B, Fournier A, Warner TD, Vane JR: Characterization of endothelin receptors mediating mechanical responses to the endothelins in the isolated stomach strip of the rat. J Pharmacol Exp Ther 1995;275:120-126.

28 Chakder S, Rattan S: Mechanisms and sites of action of endothelins 1 and 2 on the opossum internal anal sphincter smooth muscle tone in vitro. J Pharmacol Exp Ther 1999;288:239-246.

29 Imaeda K, Trout SJ, Cunnane TC: Mechanical and electrophysiological effects of endothelin-1 on guinea-pig isolated lower oesophageal sphincter circular smooth muscle. Br J Pharmacol 2002;135:197-205.

30 Imaeda K, Kato T, Okayama N, Imai S, Sasaki M, Kataoka H, Nakazawa T, Ohara H, Kito Y, Itoh M: Effects of endothelin-1 on the membrane potential and slow waves in circular smooth muscle of rat gastric antrum. J Smooth Muscle Res 2004;40:199-210. 


\section{Cellular Physiology Cell Physiol Biochem 2012;30:359-371 \begin{tabular}{ll|l} 
and BiOChemistry & $\begin{array}{l}\text { DOI: 10.1159/000339070 } \\
\text { Published online: June 29, } 2012\end{array}$ & $\begin{array}{l}\text { C 2012 S. Karger AG, Basel } \\
\text { www.karger.com/cpb }\end{array}$ \\
Kim/Chang/So: Role of ET on ICCs &
\end{tabular}}

31 Goto K, Matsuoka S, Noma A: Two types of spontaneous depolarizations in the interstitial cells freshly prepared from the murine small intestine. J Physiol 2004;559:411-422.

32 Komori S, Kawai M, Takewaki T, Ohashi H: GTP binding protein involvement inmembrane currents evoked by carbachol and histamine in guinea pig ileal muscle. J Physiol 1993;450:105-126.

33 Henry PJ: Endothelin-1 (ET-1)-induced contraction in rat isolated trachea: involvement of ETA and ETB receptors and multiple signal transduction systems. Br J Pharmacol 1993;110:435-441.

34 Henry PJ, Rigby PJ, Self GJ, Preuss JM, Goldie RG: Endothelin-1-induced [3H]-inositol phosphate accumulation in rat trachea. Br J Pharmacol 1992;105:135-141.

35 Horowitz A, Menice CB, Laporte R, Morgan KG: Mechanisms of smooth muscle contraction. Physiol Rev 1996;76:967-1003.

36 Fehr JJ, Hirshman CA, Emala CW: Cellular signaling by the potent bronchoconstrictor endothelin-1 in airway smooth muscle. Crit Care Med 2000;28:1884-1888.

37 Rockey D: The cellular pathogenesis of portal hypertension: stellate cell contractility, endothelin, and nitric oxide. Hepatology 1997;25:2-5.

38 Nussdorfer GG, Rossi GP, Malendowicz LK, Mazzocchi G: Autocrine-paracrine endothelin system in the physiology and pathology of steroid-secreting tissues. Pharmacol Rev 1999;51:403-438.

39 Kedzierski RM, Yanagisawa M: Endothelin system: the double-edged sword in health and disease. Annu Rev Pharmacol Toxicol 2001;41:851-876.

40 Davenport AP: International Union of Pharmacology. XXIX. Update on endothelin receptor nomenclature. Pharmacol Rev 2002;54:219-226.

41 Nelson J, Bagnato A, Battistini B, Nisen P: The endothelin axis: emerging role in cancer. Nat Rev Cancer 2003;3:110-116.

42 Hiraki H, Hoshi N, Hasegawa H, Tanigawa T, Emura I, Seito T, Yamaki T, Fukuda T, Watanabe K, Suzuki T: Regular immunohistochemical localization of endothelin-1 and endothelin-B receptor in normal, hyperplastic and neoplastic human adrenocortical cells. Pathol Int 1997;47:117-125.

43 Watanabe K, Hiraki H, Hasegawa H, Tanigawa T, Emura I, Honma K, Shibuya H, Fukuda T, Suzuki T: Immunohistochemical localization of endothelin-1, endothelin-3 and endothelin receptors in human pheochromocytoma and paraganglioma. Pathol Int 1997;47:540-546.

44 Huang SC: Two classes of endothelin receptors mediating contraction in esophageal muscularis mucosae. Regul Pept 2002;105:189-196.

45 Huang SC, Chang BS: Endothelin causes contraction of human esophageal muscularis mucosae through interaction with both ETA and ETB receptors. Regul Pept 2004;117:179-186.

46 Okabe H, Chijiiwa Y, Nakamura K, Yoshinaga M, Akiho H, Harada N, Nawata H: Two endothelin receptors (ETA and ETB) expressed on circular smooth muscle cells of guinea pig cecum. Gastroenterology 1995;108:5157.

47 Kitsukawa Y, Gu ZF, Hildebrand P, Jensen RT: Gastric smooth muscle cells possess two classes of endothelin receptors but only one alters contraction. Am J Physiol 1994;266:G713-G721.

48 Huang SC: Endothelin ET(A) but not ET(B) receptors mediate contraction of common bile duct. Regul Pept 2003;113:131-138.

49 Allcock GH, Battistini B, Fournier A, Warner TD, Vane JR: Characterization of endothelin receptors mediating mechanical responses to the endothelins in the isolated stomach strip of the rat. J Pharmacol Exp Ther 1995;275:120-126.

50 Hori M, Sudjarwo SA, Oda K, Urade Y, Karaki H: Two types of endothelin B receptors mediating relaxation in the guinea pig ileum. Life Sci 1994;54:645-652.

51 Sanders KM, Ördög T, Koh SD, Ward SM: A Novel Pacemaker Mechanism Drives Gastrointestinal Rhythmicity. News Physiol Sci 2000;15:291-298.

52 So KY, Kim SH, Sohn HM, Choi SJ, Parajuli SP, Choi S, Yeum CH, Yoon PJ, Jun JY: Carbachol regulates pacemaker activities in cultured interstitial cells of Cajal from the mouse small intestine. Mol Cells 2009;27:525-531.

53 Huang SC: Endothelin receptors in gastrointestinal smooth muscle. Curr Protein Pept Sci 2005;6:547-557. 